\title{
Legitimising settlement of refugees: unpacking humanitarianism from a comparative perspective
}

\author{
AHMET IÇDUYGU ${ }^{1}$, AYSEN USTUBiCi ${ }^{2,3}$, iZEM ARAL ${ }^{3}$, BALACAN AYAR $^{3}$
}

\footnotetext{
${ }^{1}$ Koç University, College of Social Sciences and Humanities, Turkey; e-mail: aicduygu@ku.edu.tr ${ }^{2}$ Koç University, Department of International Relations; Turkey; e-mail: austubici@ku.edu.tr ${ }^{3}$ Koç University, Department of Sociology; Turkey; e-mail: iaral14@ku.edu.tr, balacan.ayar@ gmail.com
}

ABSTRACT Refugee protection and humanitarianism have evolved hand in hand in the postWorld War 2 era despite shortcomings. Since the 1980s however, we have witnessed a weakening of the international protection regime and a restrictive and securitised approach to asylum. The current situation of Syrian refugees has revealed that the international protection system falls short of efficiently responding to protracted refugees situations. In the context of selective and declining humanitarianism, our analysis moves from the international context to the national context to demonstrate how government officials legitimise receiving mass numbers of refugee. This article scrutinises the political discourse of refugee reception in Turkey and Germany as two countries receiving a high number of refugees. Through analysis of political statements in both countries between 2011 and 2016, we explore how international humanitarianism has taken different shapes in the discourse of government officials. Our findings reveal the general trend that humanitarianism in the case of refugee reception manifests itself selectively, reflecting not only humanitarian obligations stemming from international law but also political, cultural and economic priorities of governments.

KEY WORDS refugees - humanitarianism - Syria - Germany - Turkey - hospitality

IÇDUYGU, A., USTUBici, A., ARAL, I., AYAR, B. (2017): Legitimising settlement of refugees: unpacking humanitarianism from a comparative perspective. Geografie, 122, 4, 449-475.

Received February 2017, accepted September 2017.

(c) Česká geografická společnost, z. s., 2017 


\section{Introduction}

Since the beginning of the conflict in Syria in 2011, three neighbouring countries, Jordan, Lebanon, and Turkey, have played a major role in receiving those fleeing from violence. Each of these three countries has taken a distinct approach to this influx of refugees. Among them, Turkey initially had an open-door policy with a strong humanitarian discourse during the settlement of refugees to designated camps in the South-eastern part of the country. With deteriorating security conditions in Syria, there has been a drastic increase in the number of Syrian refugees not only in frontline countries but also seeking to enter Europe as a spillover effect of the conflict. Since the summer of 2015, Germany has become the preferred European destination for refugees. This trend is visible in the high number of asylum applications received by Germany compared to other European Union (EU) states Syrian refugees, similar to the majority of forcedly displaced migrants around the world, are faced with a protracted refugee situation. ${ }^{1}$ Protracted situations happen when refugees are 'trapped for 5 years or more after their initial displacement, without immediate prospects for implementation of durable solutions' (UNHCR ExCon 2009). The widespread nature of protracted refugee situations reveals the inadequacy of existing responses and the rather short-term perspective inherent in the international protection system (Milner 2014, Goodwin-Gill 2016). On the one hand, democratic countries have developed formal policies towards refugees with established written traditions. On the other hand, it is still a challenge for democratically elected governments to legitimise refugee reception in a period in which humanitarianism is selective and refugees are seen as a security problem. The reception of refugees is particularly challenging for governments of countries where some sectors of public opinion on immigration and refugees tends to be negative and is unwilling to be receptive. Some research has criticised the use of humanitarian discourse to justify restrictive asylum policies (Every 2008, Chimni 2000). To our knowledge, few studies do the opposite and critically assess the selective use of humanitarian discourse to legitimise refugee reception. ${ }^{2}$

1 Here, the term 'refugee' refers to the sociological understanding of the term 'involuntary migrants - persons forced to leave their habitual place of residence because of conditions that make life there intolerable' rather than the legal status granted by individual states based on 1951 Geneva Convention Related to the Status of Refugees (Aleinikoff 1992, 121-122). Note that as Turkey still applies the territorial limitation on the implementation of 1951 Convention, those who come from other places then from Europe cannot legally become refugees in Turkey.

2 See for instance, Kirkwood (2017) for a critical review of humanising discourses towards refugees in the UK Parliament in late 2015, early 2016. 
The paper explores how these trends are reflected in the refugee reception discourses of Germany and Turkey. Both countries have received an unprecedented number of refugees over a relatively short time. Turkey has followed an open-door policy at the onset of the conflict. By early 2017, official numbers indicated that more than 2.8 million Syrian refugees had been registered in Turkey, making Turkey the country with the highest number of refugees in the world. The number of Syrian and other groups of refugees in Europe, Germany in particular, has been increasing since summer 2015 as a spillover effect of the crisis. In August 2015, German Chancellor Angela Merkel's call to European governments to take responsibility and declaration that Germany is ready to receive refugees was coupled with a relative opening of the Western Balkan route for a short period. By the end of 2015 , Germany received close to one million asylum applications, nearly one-third of which were from Syria. Officials in both countries had to counter criticism regarding the social and economic challenges presented by the reception of a high number of refugees over a short period of time. In both countries, officials initially drew attention to humanitarian responsibility in opening the borders. However in time, the humanitarian approach took different shapes.

Building on the premise that since the beginning of the $20^{\text {th }}$ century refugee issues and humanitarianism have been closely interacting with one another (Barnett 2014), this article focuses on the implications of official responses to refugee reception. Through analysis of the statements of government officials in Turkey and Germany, we suggest that economic, social, and cultural reasoning to legitimise the presence of refugees is usually prioritised over legal reasoning based on international humanitarianism. To this end, after introductory part, this article first provides a short historical overview of the context within which both countries received high numbers of refugees. The following section presents an overview of critical approaches to humanitarianism and hospitality in the context of refugee reception. The fourth section explains the methodology used for gathering political statements by incumbents and to a lesser extent by the opposition in both countries. The fifth and sixth sections provide detailed analysis of political statements regarding the reception of refugees in Turkey and Germany. Finally, the last section draws conclusions from the comparative experiences of these two countries.

\section{Background: Syrian refugee flows to Turkey and Germany}

The earliest flow of Syrians to Turkey appeared in April 2011 when the Syrian government used fatal force to crack down on anti-government protests. In the first phase of the Syrian refugee movement to Turkey, in the period of 2011-12, the pace of the refugee flows was relatively slow, and there were even some returns. 
In late 2012, the number of Syrian refugees in Turkey totalled over $14,000^{3}$ people who had taken shelter in tent cities, set up in the provinces near Turkey's border with Syria. After the failure of the Kofi Annan peace plan, in the second half of 2012, clashes in Syria escalated, and on average more than 20,000 refugees arrived in Turkey monthly. In 2013, in the second phase of these flows, there were nearly 225,000 registered Syrian refugees in Turkey. In the third phase of Syrian refugee flows to Turkey, in 2014-15, the number of refugees arriving in Turkey rocketed; in 2014, the average monthly number of refugees arriving in the country was over 100,000 . In 2015, although this monthly figure declined to around 80,000, the number of Syrians seeking refuge in Turkey was still at a very high level. In this period, while the influx of refugees continued, the camp capacities reached their upper limits, and refugees tended to find shelter outside of the camps, spreading throughout Turkey and settling mostly in urban areas (İçduygu, Millet 2016).

From the first day of the Syrian crisis, Turkey has had an open-door policy. Syrians escaping from the civil war and entering Turkey were called 'guests', not 'refugees', and generously welcomed to the country. Turkey's open-door policy was accompanied by three other policy elements: temporary protection, non-refoulement, and optimal humanitarian assistance (İçduygu 2015). Although there was a very strong political will to enact these policies, their legal grounding was somewhat weak, mainly because of two reasons: the general world-wide difficulties of legislations dealing with mass influx of refugees and the ongoing transitional period of the new Law on Foreigners and International Protection (LFIP) adopted in 2013. In the 2014-15 period, it became clear that the temporary asylum of Syrian refugees was turning into a protracted refugee situation. It was within this context that the scope and benefits of Turkey's temporary protection status were expanded by the Regulation on Temporary Protection passed in October 2014, which further facilitated access to a wide range of humanitarian assistance ranging from better shelters to health services and educational facilities as well as other social services.

However, hosting more than 2.5 million Syrian refugees in 2015, Turkey had already reached its absorption capacity (İçduygu 2016). Protection and integration services provided to these refugees had therefore remained limited and unsatisfactory. Syrian refugees in Lebanon and Jordan had shared similar experiences. Consequently, in the summer of 2015, there was a remarkable spillover effect of Syrian refugee flows into European countries. Syrians, not only those residing in Turkey, but also those staying in Lebanon and Jordan as well as Syrians coming directly from their homeland using Turkey as a transit zone, passed to Greece

3 Figures of the arriving Syrian refugees given in this section have been complied by the authors from UNHCR sources; in particular, from the specific database of UNHCR; http://data.unhcr. org/syrianrefugees/asylum.php (17.8.2017). 
and then from the Balkans to other European countries. Two European countries became the preferred destinations for settlement for these Syrian refugees: Germany and Sweden. As many countries in Europe were relunctant to receive and settle these incoming refugees, the burning question of 'responsibility sharing versus burden sharing' was hotly debated, but no satisfactory solution was offered for the reception and settlement of refugees in Europe and the developed world (Ostrand 2015).

More than a million refugees and irregular migrants crossed into Europe in 2015, creating an image of crisis as European countries struggled to cope with the influx and forcing these countries to reconsider their approaches and policies towards the resettlement of people (Holmes, Castaneda 2016). It appeared that a vast majority arrived by the Aegean Sea, but some migrants made their way over land, mainly via Turkey and Albania. Not all the refugees and irregular migrants arriving in Europe were Syrians; of course, the conflict in Syria continued to be by far the biggest driver of these flows. On the other hand, on-going violence in Afghanistan and Iraq, as well as poverty in various Asian and African countries, was also leading people to look for new lives in Europe. Consequently, Germany received the highest number of new asylum applications in 2015, with a total number of nearly 500,000 as displayed by UNHCR. But it is estimated that far more people have arrived in the country, as German officials said that more than a million had been counted in Germany's registration system as newly arrived irregular migrants and asylum seekers. ${ }^{4}$

Being promoted as the first 'real chance' to end the 'refugee crisis' in Europe by German Chancellor Angela Merkel, the EU - Turkey deal was a product of the conclusions drawn from 'the crisis of summer 2015'. In order to limit the flows of refugees and irregular migrants, the EU and Turkey agreed upon a 'one in, one out' deal in March 2016. Based on this agreement, all new irregular migrants who arrived on the Greek islands through Turkey as of 20 March 2016 would be returned to Turkey starting on 4 April 2016. For every Syrian who was sent back, one registered Syrian in Turkey would be resettled in the EU. This deal aims to prevent unauthorised migrants from entering Europe through improper channels. Moreover, Turkey has agreed to take any necessary steps to keep the passage into Europe under control. In exchange, the EU has agreed to a payment of $€ 3$ billion to the Facility for Refugees in Turkey, which will fund the support and aid efforts including housing, food, employment, education, and healthcare for Syrian migrants. In addition, visa requirements for Turkish citizens were to be lifted by the end of June 2016, 'provided that Turkey fulfils all benchmarks required for such a lift' (İçduygu, Toktaş 2016; İçduygu, Şimşek 2017).

4 "Germany on course to accept one million refugees in 2015", https://www.theguardian.com/ world/2015/dec/08/germany-on-course-to-accept-one-million-refugees-in-2015 (17.8.2017). 
Since the adoption of the EU - Turkey deal, the targeted aims have invited significant criticism both in the EU and Turkey. Only one aspect could be considered successful and at least partly satisfies the European side: there has been a considerable decline in the number of irregular border crossings between Turkey and Greece since March 2016. Apart from this, there has been very little progress with the other targets of the agreement. The EU has not been so successful in returning irregular migrants and Syrian refugees from Greece to Turkey. Only a small portion of the promised $€ 3$ billion has arrived in Turkey. The EU's decision on the visa-free regime between Turkey and the EU has been continuously delayed; consequently the political leadership in Turkey has begun to intimidate European decision-makers, indicating that if the visa requirements for Turkish citizens are not lifted, Turkey might not fulfil its obligations under this deal. While the future of the EU-Turkey deal seems to be quite uncertain, it is clear that its humanitarian component has remained quite weak from the beginning.

In the fourth phase of Syrian refugee flows, in 2016-17, it appears that new arrivals of refugees from Syria to Turkey have considerably slowed down, and Turkey's 'open-door policy' is no longer effective. In this period, it became clear for wider public that the temporary asylum of Syrian refugees had turned into a protracted refugee situation. Turkish administrators also demonstrated increasing acknowledgment that an efficacious response to the question of Syrian refugees was not to halt refugees' flight and reverse their movement, but instead required practical actions towards providing them with better settlement arrangements and opportunities to integrate into Turkish society. Hence, in January 2016, the Regulation on Work Permit of Refugees under Temporary Protection became operational, allowing refugees to apply for work permits six months after their registration under temporary protection status. In July 2016, Turkish President Erdoğan stated that Syrian refugees living in Turkey could eventually be granted citizenship. Although the details of the government's announcement to grant citizenship are not yet known, the statement indicates that the Turkish authorities have circuitously accepted the likelihood of a process whereby the protracted displacement of Syrians turns into their long-term, and even permanent, settlement (İçduygu 2016).

In this same period, Germany witnessed a significant increase in asylum applications, inviting a heated domestic political debate on asylum issues. In 2016, Germany continued to receive an increasing number of refugees; while there were nearly 47,000 newly registered asylum seekers in Germany in the last quarter of 2015; this number rose to 58,000 in the first quarter of 2016, to 73,000 in the second quarter of 2016, and finally grew to 75,000 in the third quarter of $2016 .{ }^{5}$

5 Eurostat, Asylum Quarterly Report, First time asylum applicants and first instance decisions on asylum applications: third quarter 2016; from http://ec.europa.eu/eurostat/statisticsexplained/index.php/Asylum_quarterly_report (17.08.17). 
Internationally, Germany's humanitarian gesture had two main effects on its reputation: it gained respect as a 'moral authority' and further proved its leading role in the EU. Domestically, however, these generous receiving policies of the current government became controversial, placing the refugee issue very high in the country's political agenda just before the forthcoming elections in 2017. There have been two main opposing and competing views: one is centred on halting refugees' flight and reversing their movement as happened inappropriately in the context of the EU-Turkey deal, the other is targeted toward various practical actions that provide refugees with better settlement and integration opportunities (Holmes, Castaneda 2016). The political turmoil that the reception of refugees has created in both counties needs to be contextualised in normative discussions concerning refugees and the very political context of their reception.

\section{International protection and limits of humanitarianism}

Humanitarianism generally refers to 'the moral principle to assist other human beings based on our shared humanity' (Every 2008, p. 214). The commitment to humanitarianism brings legal obligations and responsibilities to states (Brown 2010, p. 158). As far as the modern asylum and refugee regime is concerned, humanitarian obligations are institutionalised under the United Nations (UN) system. Accordingly, the 1951 Geneva Convention Relating to the Status of Refugees (the Geneva Convention) has laid the basis for the humanitarian obligation to not to send refugees back to where they will face persecution and to provide full protection rights to the refugees. The principle of non-refoulement does not limit the number of people admitted in a given territory (Owen 2016, p. 280), nor does it indicate a maximum duration of stay. In this sense, as interpreted by Benhabib, the Geneva Convention builds on and is written in the spirit of Kant's principle of universal hospitality (2004, pp. 35-36).

Meanwhile, such an interpretation takes the legitimacy of the principle non-refoulement in the eyes of the public for granted. Hence, a closer look at the drafting process of the Convention reveals that several country delegates underscored the limits of hospitality towards refugees in their respective countries. The proposal of the UN Secretary-General to negotiating states to agree to receive a number of refugees in their territory in order to relieve the burden on initial reception states was not included in the final document (Goodwin-Gill 2016, p. 688). Plus, there are inherent problems, particularly related to the case of mass flows of refugees, as the 1951 Convention operates towards the evaluation of individual cases. Additionally, the humanitarian approach envisaging short-term intervention is more suitable for emergency situations. Therefore, the UN refugee regime today still falls short of responding to mass flows and protracted refugee situations, which have become 
widespread as the frequency and duration of civil conflicts in the developing world have increased in the second half of the $20^{\text {th }}$ century. The cases of Burma, Somalia, Sudan, Afghanistan, Iraq, Libya, and recently Syria have revealed that over the last decades, mass flows and protracted situations have weakened the humanitarian aspect of protection. Rather than a broader understanding of humanitarianism as the alleviation of suffering, humanitarianism in the case of forced migration has been more focused on selective humanitarian intervention for refugee protection such as aid, repatriation, and limited quotas for refugee resettlement.

This selective humanitarianism and refugee protection needs to be contextualised in the post-Cold War context. The end of the Cold War gave rise to new security concerns. Since the 1990s, we have witnessed increasing securitisation of migration and asylum. The human mobility in general was conceptualised as a security problem for nation-states (Huysmans 2006). In this context, governments have failed to distinguish refugee movements from other migratory movements and instead embraced non-entrée policies towards all kinds of movements with populist social and security concerns. Inspired by securitised and anti-immigration debates, governments have preferred to circumvent the international protection regime and embrace a more selective humanitarian approach. For instance, the EU is willing to externalise mechanisms of control and protection to its periphery in order to also offshore its humanitarian responsibility (Bialasiewicz 2012).

The literature on humanitarianism indicates there is tension between "human rights declarations and state sovereign claims to control their borders as well as to monitor the quality and quantity of admittees' (Benhabib 2004, p. 2). As opposed to the cosmopolitan perspective on the protection of refugees that goes back to Kant's idea of hospitality as a universal right, the communitarian perspective underscores the right of political communities to control their own membership (Owen 2016). In a similar vein, Every (2008) summarises this liberal binary in humanitarian perspectives as the tension between the universalist value of 'duty to others' versus the individualist / nationalist value of minimising 'cost to self'. Accordingly, humanitarianism is the moral duty of assisting the less fortunate as long as there is a great need and the cost to self is minimal and justifiable (Every 2008, Gibney 2004).

Although the doors are more open to those fleeing persecution thanks to international law, in the context of securitisation, democratically elected governments have to legitimise their decisions to accept refugees in the eyes of the public. While research has already explored the selective and ideological use of humanitarian discourse by political elites to legitimise the exclusion of immigrants, little research looks at the use of humanitarian discourse to justify processes of refugee reception and incorporation (Kirkwood 2017, pp. 116-117). Our analysis below shows that the political discourses legitimising the settlement of refugees drift away from the humanitarian ideal of 'duty to others' and instead move towards practical discourses legitimising the arrival of a large number of refugees. The 
current discussion and political climate on how to deal with the refugee situation produced by the Syrian conflict has shown that few, if any little or no normative principles merely function for refugees. Governments ground their decisions to accept refugees on cultural, political, and economic reasoning. In other words, the human rights-based approach to refugee reception goes hand in hand with cultural, economic, and demographic discourses legitimising their acceptance to the community. Our analysis seeks to display what elements constitute the official discourse on the issue of Syrian refugees through our findings for each of the investigated countries, Turkey and Germany. Recent research has looked at discourses of refugee reception in Turkey and Germany as distinct cases (Holmes, Castaneda 2016; Kloos 2016); this article embraces a comparative approach to also reveal how discourses on refugee reception interact across cases.

\section{Analysing official discourse through media content}

In a context in which countries receive asylum seekers in a highly securitised and politicised political environment, public statements of state officials are a valuable resource to trace motives, references, and turning points. This study is based on a content analysis of statements of state officials from Turkey and Germany regarding the humanitarian, economic, cultural, and social effects of Syrian refugee reception for each country. We examined the ways in which statements on Syrian refugee flows are framed and the potential impact of these statements on public opinion and public policy. Despite the existing contra-arguments coming from opposition parties and bureaucrats against the ongoing political agenda regarding the Syrian refugee flow of the ruling parties, we mainly focused on statements from state officials to examine how politicians in power have legitimised Syrian refugee flows and settlement. Our aim is to understand how humanitarianism is legitimised in the eyes of the public and how it is fused with other discourses on economic and demographic needs, or social, political and cultural concerns.

For a comparative analysis of policy statements, a database is compiled with the help of German and Turkish speaking researchers. Statements are initially searched using general keywords related to the Syrian mass refugee movement and its spillover effects. A preliminary analysis guided us to distinguish various broad categories that are driven from cultural, economic, social, political, demographic, and legal arguments utilised to justify refugee reception. Based on these broad categories, specific keywords such as 'skilled work', 'work permit', 'brotherhood', 'hospitality', 'cultural commonalities', 'integration', and 'citizenship' were identified. Through content analysis, we divided the collected official statements cited in news items to reveal the basis of arguments for the arrival and settlement of Syrian refugees. As the data was accumulated, we observed that statements did 
not match exclusively with one category or another. Hence, each quote is analysed in terms of context, target audience, and the underlying message.

Overall, we analysed statements recalled from 41 news items from Germany and 54 news items from Turkey, retrieved from web archives of news, newspaper websites, and government sources. Some of the news items included more than one statement from various sources. The statements belong to officials of governing parties including heads of state, prime ministers, and ministers, especially of Foreign Affairs, Interior, Development, and Labour, but also to elected and appointed local politicians such as mayors and heads of provinces. To a lesser extent, we included statements from opposition parties in both countries as they responded to government officials. The database includes statements from March 2011, the beginning of civil war in Syria, until September 2016. The volume of news coverage on the issue has been changing from one year to another, according to the dynamics and its effects on each country since the conflict erupted in Syria in 2011. Germany was not affected by asylum flows until 2014 and was increasingly affected in 2015. Although Turkey was influenced by the conflict from its beginning onwards, it is documented that the issue in Turkey has become subject to public debate only after 2014. Therefore the distribution of news is not proportional per year. Plus, developments in internal politics shaped public discussion on the issue of Syrian refugees. For example, after the coup attempt on 15 July 2016 in Turkey, state officials did not focus on Syrian refugees, although from 1 July to 15 July, debates on the potential citizenship of Syrians had dominated the scene. Since Turkey is a neighbouring country of Syria, Turkish state elites have been vocal on the provision of refugee camps in border cities and the massive chaos directly affecting Turkey, including the effects on foreign policy, since the beginning of the civil war. Comments by state officials in Germany, different from Turkey, was triggered by the spillover of refugees to EU countries and particularly to Germany itself. Political statements concerning refugee settlement and protection both for EU countries and for Germany's domestic politics have become common only after 2014. All quotes in German and Turkish were translated to English by the authors.

\section{From religious brotherhood to contributing citizens: The case of Turkey}

The Turkish government, promoting a very close relationship with Syria, has adopted a prominent role in the Syrian conflict. At the onset of the Syrian conflict in 2011, the main concern of the Turkish government was to continue its ongoing close economic relations with Syria. Turkey's response to the conflict, along with a role in policy advising in Syria's domestic politics, has prioritised its cultural and economic power in Syria and its larger role in the Middle East. With the arrival of mass flow of refugees since the establishment of the first camps in November 
2011, the ruling Justice and Development Party (JDP) started to embrace a selfassertive discourse underlining that the government is capable of dealing with the infrastructural and social requirements for the refugee issue.

In 2012, as the Syrian war accelerated and Syrians began to flow to Turkey, the discourse that had prioritised the economic and political relations between two countries transformed into a welcoming, cultural discourse that was related to the notions of hospitality, state benevolence, and religious brotherhood. Along with cultural connotations, statements reveal how official discourse interprets the Syrian issue as a way of demonstrating its capacity and economic power to national and international audiences. These three notions are also the main elements of the JDP's response to legitimise its policies and practices to counter criticisms coming from the political scene. For instance, Minister of Foreign Affairs Ahmet Davutoğlu in December 2012 responded to arguments regarding the possible negative economic consequences of Turkey's open-door policy. He stressed that Turkey is powerful enough to host these people in camps. ${ }^{6}$ In Davutoğlu's statement, the government's emphasis on a zero-problems with neighbours and open-door policy towards Syria is evidently supported by a discourse of (economic) power and a tradition of benevolence. Officials further argue that hospitality and benevolence for those in need are fundamental elements of Turkish tradition and culture.

These attributions refer to a selective humanitarianism within which brotherhood and Muslimhood are prioritised over rights-based humanitarianism founded on normative values derived from international law. For the JDP, these essential elements of Turkish culture that make the aid and open-door policy inevitable are also a sign of national superiority. As Ministry of Interior İdris Naim Şahin stated: "All those people are sacred beings that Allah created, therefore we believe to share the bread and water that we have. This is why Turkey and the Turkish nation have always a superior and precious position among other nations." Şahin's statement clearly demonstrates an emphasis on national superiority enabled through state benevolence in the official rationale. Yet, these cultural references remain vague and do not adequately answer 'how' and 'in what conditions', the humanitarianism towards refugees would unfold. The analysis of political statements of the governing party reveals that the government had assumed a temporary stay of refugees, instead of long-term and permanent settlement, based on the expectation that the conflict would be over in a relatively short time. This assumption also led to short-term solutions to ill-defined

6 Dışişleri Bakanı Ahmet Davutoğlu Açıklaması ('Statement from Minister of Foreign Affairs Ahmet Davutoğlu'), http://www.haberler.com/disisleri-bakani-ahmet-davutoglu-aciklamasi4204922-haberi/ (17.8.2017).

7 Bakan Şahin: İnsanlar Türkiye'de yaşamaya can atıyor ('Minister Şahin: People are striving for living in İstanbul'), http://www.ensonhaber.com/bakan-sahin-insanlar-turkiyede-yasamaya-can-atiyor-2012-09-25.html (17.8.2017). 
problems, such as the limited capacity of camps and and inability to sustain basic rights due to an ever-increasing number of refugees.

Although official statements were constructed on the temporariness of the situation until 2013, the question of long-term or permanent settlement of refugees has since started to arise. Yet, these statements did not match any policy initiatives, as also criticised by the opposition. In 2013, a speech by Ahmet Davutoğlu in one of the earliest statements implies the possibility of the permanent stay of Syrian refugees in Turkey. Davutoğlu was then the Minister of Foreign Affairs and gave a speech during the opening of the Syrian Turkmen Assembly: "I hope that they [Syrians] will go back their homeland immediately; each of you [Turkmen Syrians] will go back to your warm houses. But you should know that if you have to stay here, our home is yours, our food is your food, and our fate is your fate. Because we not only open our doors and houses, but also open our hearts to you."

Despite the welcoming official discourse, officials' definition of Syrian refugees as 'guests' disregards the tensions inherent in the discourse of hospitality. For instance, the Governor of Antalya reminds the public of the temporariness of the situation and the acceptance criteria of 'proper' guests: "As long as they act properly, do their own work and keep away from criminal involvement/activity including begging. We have been trying to find ways to live together with them as much as we can do, but principally, the plan is not to keep Syrian refugees permanently here in Antalya."

As is clear in this statement, the term hospitality is Janus-faced. Hospitality carries a dangerous uncertainty, as hosts cannot be sure of the intentions of guests. In protracted situations, hospitality can easily turn into hostility, as observed by Jacques Derrida (Carpi 2016). On the one hand, 'the traditional hospitality myth refers to the respect, tolerance and embracement of the stranger' (Yücebaş 2015, p. 38). On the other hand, hospitality is a myth with a dark side, as articulated by Yücebaş: "The myth has a function to naturalize and reproduce what is deemed to be 'the culture'. It approves the 'us' and distinguishes 'we' from the other." (Yücebaş 2015, p. 38) The dilemma between cultural humanitarianism and the use of othering language that constructs a 'we', propels a demarcation between 'proper' and 'improper' guests that puts Syrian refugees in a more vulnerable position.

While this discourse highlights the capacity of Turkey and the culture of hospitality based on religious brotherhood, the year of 2013 and the beginning of 2014

8 Dışişleri Bakanı Davutoğlu “Türkiye Suriyeli Türkmenlerin yanında olmaya devam edecektir” ('Minister Davutoğlu “Turkey will continue to stand by Syrian Turkmen"'), http://www.mfa. gov.tr/disisleri-bakani-davutoglu-turkiye-suriyeli-turkmenlerin-yaninda-olmaya-devamedecektir.tr.mfa (17.8.2017).

9 Patronlar İstiyor, Suriyeli Göçmenler Ucuz İşçi Olarak Kullanılıyor ('Bosses want, Syrian Refugess are used as cheap labour'), http://haber.sol.org.tr/emek-sermaye/patronlar-istiyor-suriyeligocmenler-ucuz-isgucu-olarak-kullaniliyor-103817 (17.8.2017). 
marked a transition in the way in which government officials presented the issue of refugee reception. As temporary stay was beginning to transform into permanent settlement, the question of integrative policies tightly related to the economic and legal arena began to dominate the official discourse. State officials making promises on economic regulations regarding the labour force participation of Syrians from 2014 onwards signal their increasing economic concern with the long-term settlement of refugees. In a speech about the wages of Syrian refugees, Faruk Çelik, the Minister of Labour and Social Security, promised to protect the labour force before providing job opportunities to Syrian refugees. ${ }^{10}$ The tone of statements changed, focusing more on integration policies with long-term calculations in terms of 'cost to self' within a developmental approach, especially after 2015. Developmental elements prioritise maximising the benefit coming from the human resources and economic capital of refugees. Since the focus has sharply turned to economic rather than humanitarian concerns, these kinds of statements overlook the need to improve the social and economic conditions that refugees live in.

Fatma Şahin, the Mayor of Gaziantep underlines the economic benefits coming with the Syrian influx to the city, which received the second highest number of Syrian refugees: "In the process [referring to civil war in Syria], the collapse of Syrian industry has risen Gaziantep's industry. The refugee flow also includes doctors and engineers. Those contribute to the city with their expertise. We should not forget these points while evaluating Gaziantep." 11 This statement shows refugees as a potential source of development and economic contribution rather than passive recipients of assistance only. On the other hand, economic arguments had already been mounted in 2013 by the previous mayor of Gaziantep Asım Güzelbey. He mentioned the inefficacy of policies and how Turkey failed to keep qualified Syrians within its borders: "Since legal work permission will not be given to Syrian refugees, they fled from Turkey to other countries." 12

Another crucial statement is from Faruk Çelik, Minister of Labour and Social Security, regarding the economic impact for both host communities and refugees. He explains that the legal permission of Syrians to work would not affect local people's employment and it would decrease the need for low-skilled workers. According to him, Syrian refugees could cover vacancies in both part-time and seasonal sectors through the employment of up to 100,000 workers. ${ }^{13}$ With the proposed new regulation, including paying a premium to refugees and prohibiting

10 Suriyeli İş̧̧ilerin Alacağı Maaş Belli Oldu ('The Salary of Syrian Workers is determined'), http:// www.sabah.com.tr/ekonomi/2014/11/13/suriyeli-iscilerin-alacagi-maas-belli-oldu (17.8.2017).

11 OŞehirde Balon Şişti ('The city that had a boom'), http://www.haberturk.com/ekonomi/emlak/ haber/1065528-o-sehirde-balon-sisti (17.8.2017).

12 Suriyeli Parasinı da Getirdi ('Syrian Refugees brought their money as well'), http://www.sabah. com.tr/ekonomi/2013/11/12/suriyeli-parasini-da-getirdi (17.8.2017). 
compensation under minimum wage, Turkish citizens would not be victims in the labour market. This kind of statement focuses on an integration discourse to reduce the tension between locals and refugees.

As the developmental elements dominate the official agenda, specifically targeted economic and legal measures appear in debates, such as the introduction of work permit application procedures and granting citizenship to Syrian refugees. As will be discussed in the next section, this turn towards a relatively rights-based humanitarian discourse interacted with the EU's humanitarian discourse that was on the rise especially in 2015. In 2016, legislative changes on work permits aimed to engage the human capital coming from Syria. To legitimise the introduction of the work permit application procedures for Syrian refugees, and subsequently for other asylum seeking groups, the official statements keep relying on discourse emphasising the economic value of Syrians and how Turkey can benefit from refugees that stay in Turkey. Having acquired work permission, skilled and educated Syrians can work and will not flee to Europe, Syrian businessmen with capital can invest in Turkey, and employment vacancies can be filled with Syrians. Deputy Prime Minister Yalçın Akdoğan's explanation reflects this rationale emphasising the need for both a qualified and unqualified labour force: "European countries keep announcing and accepting Syrians in certain categories of skilled labour force. Turkey has shortages in certain fields. There are also some other fields in which slightly less qualified people can work. The Labour Agency makes announcements for open positions in certain fields but no one would apply. Syrians can be employed in various fields. If we hadn't issued work permits, the qualified labour force would have gone to other countries and we would have been left with a much different picture." 14

Two developments have paved the way for legislative changes that embrace a utilitarian perspective on the settlement and labour force participation of refugees. On the one hand, officials realised that short-term policies and the expectancy of temporariness has left the labour market inaccessible for the human capital coming from Syria. On the other hand, these discursive and legislative changes interacted with developments in the EU especially in 2015. As we will see in the example of Germany, the EU opened its borders for the arrival of refugees while some officials in Germany embraced a discourse on the economic contribution of refugee communities. Arguably, officials in Turkey were influenced by such emerging discourses in the EU, particularly in Germany.

13 Suriyeliler Tarım İş̧isi Oluyor ('Syrian Refugees became agricultural workers'), http://www. ulusaltarim.com/3761/Suriyeliler-tarim-iscisi-oluyor (17.8.2017).

14 Türkiye beş Yıl Sonra Nitelikli Mültecileri Kaptırmamaya Karar Verdi ('Turkey Decided Not to Lose Qualified Syrian Refugess after Five Years'), http://www.al-monitor.com/pulse/tr/originals/2016/01/turkey-syrian-refugees-granted-right-to-work.html (17.8.2017). 
In reply to the EU's opening borders and the perception that the EU was attracting the best and brightest amongst Syrian refugees, officials raised the will to settle skilled refugees in Turkey. For instance, Deputy Prime Minister of Turkey Numan Kurtulmuş stated in a press briefing after the Council of Ministers' meeting: "Certain people used to come here on brain-hunting missions, taking the highly qualified, educated Syrians to their countries. The Syrians are not just children selling tissues at traffic lights." ${ }^{15}$ As seen in the statements, working permission is legitimised with a dominant discourse of preventing Europe from seizing the skilled and educated refugee population and benefiting from them for the sake of Turkey's own economic development.

In July 2016, President Erdoğan started the debate on citizenship when he said: "I believe among our brothers [referring to Syrian refugees], there are fellows desiring to become Turkish citizens. Steps are taken by the Ministry of Interior Affairs." 16 The brief announcement about citizenship soon turned out to be a total game-changer for the whole refugee settlement debate as follows: "Considering the points of our shared values, we benefit from these people while eradicating their inhuman living conditions." ${ }^{17}$ The government promotes that granting citizenship according to existing national citizenship law is part of the natural process set in motion by the right to work. Moreover, the citizenship debate emerges as a way of combining cultural motives like shared values and economic impulses of improving the economy. As a response to the opposition's critiques of 'population engineering', the government in return refined their political statements towards the citizenship prospects of Syrians, as exemplified in Minister Veysel Eroğlu's statement on citizenship: "Absolutely there will be criteria. Especially those will be investigated. Improper ones will not be citizens. Europe was quick. There were a lot of well-educated people in Syria. Europe grabbed them straight away; I mean Europe is so vigilant without any support. Academics, experts, Europe accepted the chosen ones at once... Now we take care of 3 million Syrian brothers and sisters. They are supposed to help. The aid hasn't arrived. We still expect to receive it." ${ }^{18}$

15 Turkey Grants Syrians Right to Work, But Is It Too Little, Too Late?, http://www.al-monitor.com/ pulse/originals/2016/01/turkey-syrian-refugees-granted-right-to-work.html (17.8.2017).

16 Erdoğan'dan Türkiye'deki Suriyelilere Vatandaşlık Açıklaması ('Declaration of Citizenship by Erdoğan to Syrian Refugees in Turkey'), http://www.bbc.com/turkce/haberler/2016/07/160703_erdogan_suriyeliler (17.8.2017).

17 Erdoğandan vatandaşlık açıklaması: Kalifikasyonu çok yüksek Suriyeliler var ('Declaration of Citizenship by Erdoğan: There are Syrian Refugees with Very High Quality'), http://www.bbc. com/turkce/turkiye/2016/07/160705_erdogan_suriyeliler (17.8.2017).

18 Eroğlu: Türkiye Suriyelilerin Duası ve Berektiyle Büyüyor ('Turkey grows with the prays and plentitudes of Syrians'), http://www.aljazeera.com.tr/haber/eroglu-turkiye-suriyelilerinduasi-ve-bereketiyle-buyuyor (17.8.2017). 
As the statement indicates, the selection criteria of Turkey interacts with the EU's, especially Germany's, policy and discourse. While criticising the EU's selective humanitarianism for being discriminatory by picking only skilled individuals, the Turkish government articulates a very similar selective mechanism that desires to keep the skilled refugee population within its borders. JDP Group Deputy Chairman Bülent Turan declares: "For example, they ask 'Could every Syrian be citizen?' No. We have 8-10 criteria that should be met with the data of our security organizations such as having a clean record, speaking Turkish, and adding value to Turkey as a citizen... If (Syrians) want to produce, come and serve for Turkey; if (Syrians) add value to Turkey, we will hold you dear." ${ }^{19}$

In this sense, the citizenship discourse is based on a definition of being a 'proper citizen' similar to earlier discourse on being 'proper guests'. However, here, the discourse legitimising the presence of refugees has changed into a cost-benefit calculation based on their economic contribution. Hence, the requirement of being 'proper' justifies a selection that rests on economic terms such as producing, serving, and adding value instead of a selection on cultural terms.

Between 2011 and 2016, the focus of official statements legitimising the reception and settlement of Syrian refugees in Turkey has shifted from one form of selective humanitarianism based on shared culture and religion to another form of selective humanitarianism indicating the need to integrate skilled, educated Syrian refugees because of their potential to contribute to economic development. We suggest that the discursive turn from a temporary presence to permanent settlement, from religious brotherhood to economically deserving potential citizens cannot be discussed without reference to changing discourses on refugees in the EU. The next section analyses the case of Germany, as the country leading and shaping the EU's refugee reception policies.

\section{Demographic, economic vs. societal concerns: The case of Germany}

In the case of Germany, officials have increasingly talked about the impact of refugee flows following the acceptance of refugees to the country. Our analysis shows that officials in Germany were initially concerned, in 2014, with sharing the responsibility for the arrival of Syrian refugees by all European countries. Since 2014, Germany has been calling on other EU countries to take measures such as accepting refugees and applying an open door policy for refugee arrivals

19 İktidardan Kritik Açıklama: Her Suriyeli Türk Vatandaşı Olamayacak ('Critical Declaration from the Government: Not Each Syrian will be able to get Citizenship from Turkey'), http:// www.hurriyet.com.tr/iktidardan-kritik-aciklama-her-suriyeli-turk-vatandasi-olamayacak-40131968 (17.8.2017). 
in order to prevent refugee deaths on the route to Europe. German officials have been critical of EU countries as well as their own country for acting too late both in terms of introducing legal measures and organising a concerted humanitarian intervention. As stated by Development Minister Gerd Müller, in 2014: "We are witnessing the disaster of the century. Many deaths will occur in the coming winter if we do not make a clear combined effort. I am missing the EU's humanitarian flag. Germany has already done its homework and serves as a role model. If the remaining 27 member states would involve themselves according to their size and capability, like Germany, then we could secure the survival of families and children and offer them long-term prospects." 20

The discourse that Germany presents a 'role model' enhances the country's position in the international and national contexts. As the country hosting the most refugees among EU members, German officials praise its refugee politics and its leading role in the EU and criticise other members of the Union. Merkel explicates the government's policy of refugee acceptance and criticises the EU and Germany for neglecting the ongoing refugee issue for a long time: "There are political issues that one can see coming but don't really register with people at the exact moment and in Germany we both ignored the problem for too long and blocked out the need to find a pan-European solution. Germany will remain Germany - with all that is dear to us." ${ }^{21}$

Referring to the failure of a 'pan-European solution', Germany consolidates its leading role, which is linked to Germany's history of migration, as 'Germany will remain Germany' and a national superiority discourse regarding the humanitarian issue. In this sense, Germany separates itself from other EU countries, not only by being economically capable of sustaining a humanitarian regime, but also by being morally superior to other EU countries. National superiority can be related to the acknowledgment of the humanitarian responsibility of accepting the refugees.

As the preceding statements show, official German discourse focused on the fact that humanitarian responsibility has always been intertwined with the economic agenda and demographic concerns, underlining the potential contribution of refugees to the national economy. As Chairman of the SPD Parliamentary Group Thomas Opperman argued, the incoming qualified refugees may be a great chance for a change in Germany's demography while well-educated refugees' children

${ }^{20}$ Jahrhundertkatastrophe in Syrien und Nordirak Sieben Millionen auf der Flucht ("“Catastrophe of Century" in Syrian and North Iraq: Seven Million People on the Run'), https://www.mainpost. de/ueberregional/politik/zeitgeschehen/bdquo-Jahrhundertkatastrophe-ldquo-in-Syrienund-Nordirak-Sieben-Millionen-auf-der-Flucht;art16698,8399333 (18.8.2017).

${ }^{21}$ Merkel raumt Fehler ein ('Merkel concedes Failure'), http://www.zeit.de/politik/deutschland/ 2016-08/fluechtlinge-bundeskanzlerin-angela-merkel-fehler (18.10.2017). 
may well adapt to language courses and schools in Germany which will eventually bring a long-term labour force to the country. ${ }^{22}$

The economic agenda dictates finding a match between Germany's demographic and economic needs and the skilled refugees. Since the beginning, Germany has implemented a very calculative policy towards Syrian refugees by applying selective migration and creating policies by considering the future goals and targets of integration with refugees. Earlier statements in 2014 mostly approved the demand of policy making for the integration of Syrian refugees into the labour market. In order to address the challenge of an aging population, policy makers referred to the need for selective migration in receiving refugees. For instance, in 2014 Frank Walter Steinmeier, Minister of Foreign Affairs, offered opening a 'second door' for 'qualified migration' which would reduce the number of asylum seekers and could be an answer to demographic challenges and the deficits of the German job market. ${ }^{23}$

The humanitarian concerns of hosting refugees in the existing economic and political conditions pave the way for articulating policies regarding the refugee issue in relation to other policy domains especially demography and the labour market. In other words, articulating normative humanitarian values, German officials have always perceived the refugee issue with an agenda of integrative policies that envisage the incorporation of refugees into the labour force and social life. Most of the official statements in 2014 agree upon the necessity of integration into the labour market. Rather than a mere humanitarian discussion on the acceptance of the refugees, German official discourse has given priority to the possible economic opportunities of refugee flows for the country.

As a consequence of this consensus, discussions have revolved around the potential of refugees in terms of their possible adaptation into the labour market. Therefore, the statements bring to light selective responses to migration that emphasise 'qualified' and 'educated' Syrians who arrived in Germany as refugees. After that, the discussion has turned around how to use these skilled and educated middle-class refugees to cover the skill shortage of Germany in order to optimally benefit from the potential labour force. The President of the Association of German Chambers of Industry and Commerce Eric Schweitzer has mentioned his high expectations from migrants because of their potential to prevent a skill shortage in

22 SPD - Fraktionschef fordert Bleiberecht für Kinder, die Deutsch sprechen ('SPD - Head of Parliemantary Party demands right for residence for children who speak German'), http://www. spiegel.de/politik/deutschland/zuwanderung-thomas-oppermann-bda-und-arbeitsagenturfuer-reformen-a-1044351.html (9.9.2017).

${ }^{23}$ Rede von Aussenminister Frank-Walter Steienmeier zur Eröffnung des Wirtschaftstages der Botschafterkonferenz 2015 ('Speech from Minister of Foreign Affairs Frank Walter Steinmeier on the opening of Economy Days of the Embassy Conference'), http://www.auswaertiges-amt. de/DE/Infoservice/Presse/Reden/2015/150825-BM-BokoWita.html (18.8.2017). 
Germany. ${ }^{24}$ From an economically liberal perspective, he even added that the legal minimum wage would have to be abolished and low-wage sectors subsidised to make use of the potential of refugees. This implies that selective humanitarianism emphasising the low cost to oneself may even lead to the exploitation of refugees by the German economy at an acceptable degree.

Despite a rather optimistic perspective on the refugee issue, Hans-Werner Sinn, a member of the advisory council of German Economy Ministry, criticises that most of the Syrian refugees, including those within the appropriate age group eligible for the job market, are unqualified for substituting the skills shortage in Germany. ${ }^{25}$ This is one of the few statements referring to the unskilled labour of refugees whereas the official discourse has always centred on skilled labour. Another statement in 2015 from the Federal Office for Migration and Refugees (BAMF) tries to find a compromise for refugees' attendance in the labour market. ${ }^{26}$ Indicating that if Germany is looking for a proper response to the Syrian influx, appropriate qualification of migrants should be ensured. BAMF states that since the skills shortage in Germany is rather limited to certain sectors, specifically healthcare and nursing, as well as to certain regions in Germany, the skills shortage will become a more pressing issue if the state doesn't formalise and integrate the skill shortage issue into a law on immigration.

The ongoing economic integration debate proceeds with a legal emphasis in 2016. The official discourse of Germany reflects that the government is eager to welcome refugees as long as they match with the country's needs. Followed by a legal process that eases the integration of Syrians into the workforce, Chancellor Angela Merkel expresses the government's will to collaborate with business organisations and designate policies upon the demands of business and trade organisations such as reducing the bureaucracy of integrating the refugees into the labour market. ${ }^{27}$ In this sense, the collaborative atmosphere between business

${ }^{24}$ Wirtschaft setzt auf Flüchtlinge ('Economy relies on refugees'), http://www.schwaebische. de/wirtschaft/aktuelle-nachrichten_artikel,-Wirtschaft-setzt-auf-Fluechtlinge-alsFachkraefte-_arid,10136257.html (18.8.2017).

${ }^{25}$ İfo-President Sinn: Flüchtlinge lösen Fachkraftmangel nicht ('ifo-President Sinn: Refugees could not solve skills shortage'), http://www.sueddeutsche.de/news/karriere/arbeitsmarkt-ifo-chef-sinn-fluechtlinge-loesen-fachkraeftemangel-nicht-dpa.urn-newsml-dpacom-20090101-151014-99-08351 (18.8.2017).

${ }^{26}$ Bestimmung von Fachkräfteengpässen und Fachkräftebedarfen in Deutschland ('Identification of skilled labour and skilled labour demand in Deutschland'), http://www.bamf.de/SharedDocs/ Anlagen/DE/Publikationen/EMN/Studien/wp64-emn-bestimmung-fachkrafteengpaesseund-bedarfe.pdf?_blob=publicationFile (18.8.2017).

27 Flüchtlinge sollen leichter an Jobs kommen ('Refugees should be employed easier'), http:// www.stuttgarter-zeitung.de/inhalt.angela-merkel-fluechtlinge-sollen-leichter-an-jobskommen.4462c3c3-7ffd-4823-aafa-8b3353588d19.html (18.8.2017). 
organisations and government was enhanced by legal steps and strengthened the economic integration discourse. Merkel stated that Germany is preparing the firstever integration legislation that carries certain duties with it for every person who comes to Germany. Legislation puts emphasis on refugees participating in the workforce, removing the barriers to the labour market, and creating 100,000 low-paid jobs for asylum seekers that are supported by language courses and job training. ${ }^{28}$ Here, Chancellor Merkel acknowledges that incoming refugees are not necessarily skilled workers as they arrive. Rather, they are expected to gain skills while they are in Germany. Merkel continues: "We will have a German law on integration. This is the first time in post war Germany that this has happened. It is an important and qualitative step." ${ }^{29}$ Merkel and her leading party in the government promote the integration package by referring to national superiority, as encapsulated by the slogan, 'Wir schaffen das'30 ('We can do it'), the prominent motto used to indicate Germany has the capacity to overcome the challenge posed by the reception of refugees in mass numbers.

The discussion on economic integration fuels the integration discourse of officials from both incumbent and opposition sides. Even social democrats, the junior partner of Merkel's coalition government, contest the predominant focus of the legislation process on the integration of refugees into the work force. SPD Vice Head Ralf Stegner says, regarding the government's attempts, the aim should be 'to integrate refugees, not bully them' and adds 'where there is a lack of free will, there will also be consequences' ${ }^{31}$ implying a lack of social perspective in the proposed legislation. Government efforts to promote refugee settlement from an economic perspective have not been enough to stem criticism coming from right-wing opposition regarding the rise of Islam and disturbance of social order.

In a televised interview, Hansjörg Müller, an official from the right-wing populist party Alternative for Germany (AFD) that gained widespread support after the arrival of refugees in big numbers, criticises the government for undermining

${ }^{28}$ Merkel und Gabriel nennen Integrationsgesetz -historisch- ('Merkel and Gaabriel call Integration Law - historic'), http://www.spiegel.de/politik/deutschland/grosse-koalition-merkel-undgabriel-nennen-integrationsgesetz-historisch-a-1087160.html (18.8.2017).

29 Pressekonferenz von Bundeskanzlerin Merkel, Bundesminister Gabriel and Minister-präsident Seehofer ('Press Conference of Chancellor of Germany Merkel, Federal Minister Gabriel and Prime Minister Seehofer'), https://www.bundeskanzlerin.de/Content/DE/Mitschrift/ Pressekonferenzen/2016/04/2016-04-14-merkel-gabriel-seehofer.html (18.8.2017).

30 Seehofer greift Merkel an: So wie bisher wir schaffen das nicht ('Seehofer assaults Merkel: Thus far we can't do much'), http://www.swp.de/ulm/nachrichten/politik/seehofer-greift-merkelan_-_so-wie-bisher-schaffen-wir-das-nicht_-13576919.html (18.8.2017).

31 'Germany tells refugees: Integrate or lose your right to live here permanently', https:// qz.com/650683/germany-tells-refugees-integrate-or-lose-your-right-to-live-here-permanently/ (18.8.2017). 
the constitutional order and immigration law. He calls on the government to distinguish between economic migrants and refugees. ${ }^{32}$ Referring to the notion of economic burden, the leader of AFD, Frauke Petry, criticised the government's agenda as follows: "This fairytale of migrants coming to Germany and being an enriching factor to our economy has been proven to be false and there are no concepts from our government on how to deal with the situation." ${ }^{33}$ Hansjoerg Muller, an official at the AFD's Bavarian branch, continues: “The vast majority of refugees coming to Germany aren't refugees, [they] have been living in refugee camps in Turkey [and] don't come from war areas. These people only seek a better life." 34

Another counterpoint of the opposition is the government's lack of attention to disruption of social order in the medium- and long-term, especially after the terror attacks carried out by two asylum seekers in Munich, Würzburg, and Ansbach. Boris Palmer, the Mayor of Tübingen from the Green Party, a controversial figure who is known to be close to the AFD, calls for strict border security and a limit to the number of asylum seekers in Germany: "Five years ago I would have rejected this argument. However, now we have a million refugees in the country-20 times more than five years ago. So the risk of being a victim of refugee violence is 20 times higher. People notice that. Every week, there's a report in the newspaper about a violent refugee somewhere nearby." ${ }^{35}$ As his statement shows, the terror attacks rallied the oppositional discourse that directly equates refugees with criminal activities and violence and implicitly with international terrorism.

Despite criticism of Merkel's refugee policies for allegedly leading to the disturbance of social order, prompting instead the securitisation of asylum and linking refugee issues to terrorism, Merkel emphasises: "Let me be clear, we are at war with Islamic State, not with Islam." ${ }^{36}$ Parallel to the acceptance of refugees and incidents of terror in Germany and around Europe, the right-wing AFD, as a leading critic of governmental policies towards refugees, gained a significant amount of votes in the state parliamentary elections. ${ }^{37}$ Although Merkel refrained from giving

32 AfD is the only party that really cares about refugees - senior Afd Member to RT, https:// www.rt.com/news/338076-refugee-europe-afd-border/ (18.8.2017).

33 Expecting migrants to enrich German Economy is fairytale - Afd leader to RT, https://www. rt.com/news/347514-germany-refugees-afd-party/ (18.8.2017).

${ }^{34}$ AfD is the only party that really cares about refugees - senior Afd Member to RT, https:// www.rt.com/news/338076-refugee-europe-afd-border/ (18.8.2017).

35 Ich bleibe bei meiner Meinung ('I adhere to my opinion'), https://www.welt.de/print/wams/ debatte/article157654562/Ich-bleibe-bei-meiner-Meinung.html (18.8.2017).

${ }^{36}$ Merkel bleibt beim "Wir schaffen das" (Merkel remains at "We can do this"), http://www.zeit. de/politik/deutschland/2016-07/angela-merkel-anschlaege-ansbach-wuerzburg-pressekonferenz (18.8.2017).

37 The Rise of Populists A Problem for Merkel and Germany, http://www.spiegel.de/international/ germany/rise-of-populist-afd-a-problem-for-merkel-and-germany-a-1110954.html (18.8.2017). 
a direct answer to the AFD, she comments on her party's defeat in the regional elections as: "We have to recognize that the population doesn't have enough confidence in our ability to resolve these issues even though we've already achieved a lot. [...] I still consider the decision as it was made to have been the right one and now we need to continue to work on it." ${ }^{38}$

The rise of right-wing parties is often explained as a successful interpretation of societal concerns regarding the order and security of the country in a conservative and xenophobic discourse and practices. For instance, although withdrawn after his statements incited massive criticism, AFD Deputy Leader Beatrix von Storch stated in 2016 regarding the refugees at the Germany border that 'the use of firearms against children is not permitted but women are a different matter. The use of weapons against them can therefore be permitted within the narrow legal framework' ${ }^{39}$ In this regard, despite the economic integration emphasis, the society and the potential effects of refugees are frequently discussed in a provocative and anti-humanitarian tone, despite the government's effort to relieve tension concerning the Syrian issue in society. In this sense, the German case reveals the very thin line between hospitality and hostility and the impact of the securitised context governments have to deal with when receiving refugees.

\section{Conclusion}

It is well observed that the humanitarian regime, as it is practised, falls short of providing a durable solution and full protection to the majority of refugees in the world. It also fails to respond to the integration needs of refugees in a protracted situation. The development of events in the aftermath of the Syrian conflict and emerging discussions among refugees are a testament to this deficit in the current regime. Interestingly, developing countries such as Lebanon, Jordon and Turkey, at the periphery of Europe and bordering Syria, as well as Germany, with the biggest economy in Europe, have been generous in admitting refugees. After portraying the factual development of events since 2011, this article provided a theoretical discussion of the implications of humanitarianism in relation to refugee reception in the post-Cold War period. In this context, characterised by securitisation of

${ }^{38}$ Kanzlerin übernimmt Verantwortung für Wahlergebnis ('Chancellor takes the responsibility of election results'), from https://www.welt.de/politik/deutschland/article157956516/Kanzlerin-uebernimmt-Verantwortung-fuerWahlergebnis.html (18.8.2017).

39 AfD-Vizechefin will Polizei sogar auf Kinder Sciessen lassen ('AfD Vice Chief wants to let police shoots children'), http://www.faz.net/aktuell/politik/fluechtlingskrise/beatrix-von-storchafd-vizechefin-will-polizei-sogar-auf-kinder-schiessen-lassen-14044186.html (18.8.2017). 
asylum and a restrictive approach to immigration in general, governments receiving a high number of refugees may have a variety of motivations for engaging in humanitarian action. Although most of the national and international institutions admit that the Syrian refugee issue is a matter of humanitarianism, humanitarian intervention has taken different forms based on social, political, and economic agendas as well as cultural motives.

Our analysis in this paper moved from the international context of humanitarianism to the context of national policies. We have focused on official statements in two countries which have recently received a high number of refugees. In our examination of the official discourse of Turkey and Germany towards Syrian refugees, we found that humanitarian discourse initially served the social, political, cultural, and economic priorities of the governments of each country. Since the beginning, Turkey's official discourse of humanitarianism towards those fleeing conflict in Syria has mainly been based on the benevolence of a strong state and the tradition of hospitality especially towards fellow Muslims. In contrast to Turkey, Germany's official discourse has given priority to the economic consequences strengthened by a cultural and historical emphasis on the country's leading role in the EU. Arguably, only after Merkel and other officials in Germany placed a strong emphasis on refugees' potential contribution to the German economy, officials in Turkey have changed their discourses and taken steps towards facilitating procedures allowing Syrians under temporary protection to work legally. In this sense, policies targeting Syrian refugees in Germany might have influenced Turkey.

Demographic needs and maximising the refugees' capital, however, challenge normative humanitarianism by referring to certain qualifications of refugees such as 'skilled' or 'proper' and constituting categories in which some will fit and others will not. The acceptance and settlement of refugees have brought forward in both countries concerns of security and social order. While the incumbent governments respond to concerns by emphasising the benefits coming from refugees, the opponents counter with security and order problems that may escalate xenophobic reactions at the societal and political level. Increasing attacks on refugee settlements both in Germany and in Turkey, and of negative attitudes towards refugees already provide evidence of xenophobia. In fact, the tension between hospitality and hostility is felt in reaction towards refugee reception in both countries.

On the one hand, states are interested in distinguishing economic migrants from refugees and have their doors more open to the latter. On the other hand, it is no longer desirable to convey asylum seekers as dependent on welfare (Gibney, Hansen 2003, p. 4), hence as cost to self. As seen in the analysis, there is a trend towards emphasising the economic contribution of asylum seekers. Consequently, we suggest that governments should work for more receptive policies and public attitudes towards refugees (Gibney 2004, Every 2008). In addition to it, our study calls into question and invites further research that investigates whether 
membership-based economic contributions provide a better ground to legitimise the reception of refugees, especially in the context of declining humanitarianism as a moral obligation to others.

\section{References}

ALEINIKOFF, T.A. (1992): State-centered refugee law: From resettlement to containment. Mich. J. Int'l L. 14, 120-138.

BARNETT, N.M. (2014): Refugees and humanitarianism. In: Quasmiyeh, E.F., Loescher, G., Long, K., Sigona, N. (eds.): The Oxford Handbook of Refugee and Forced Migration Studies, 241-253.

BENHABIB, S. (2004): The Rights of Others: Aliens, Residents and Citizens. Cambridge University Press, Cambridge.

BIALASIEWICZ, L. (2012): Off-shoring and out-sourcing the borders of Europe: Libya and EU border work in the Mediterranean. Geopolitics, 17, 4, 843-866.

BROWN, C. (2010): The Only Thinkable Figure? Ethical and Normative Approaches to Refugees in International Relations. In: Betts, A, Loescher, G. (eds.): The Refugees in International Relations. Oxford University Press, Oxford, UK, 151-168.

CARPI, E. (2016): Against Ontologies of Hospitality: About Syrian Refugeehood in Northern Lebonan. Published on $27^{\text {th }}$ October, 2016, http://www.mei.edu/content/map/againstontologies-hospitality-about-syrian-refugeehood-northern-lebanon (30.11.2016).

CHIMNI, B.S. (2000): Globalization, humanitarianism and the erosion of refugee protection. Journal of Refugee Studies, 13, 3, 243-263.

EVERY, D. (2008): A Reasonable, Practical and Moderate Humanitarianism: The Co-Option of Humanitarianism in the Australian Asylum Seeker Debates. Journal of Refugee Studies. 21, 2, 210-229.

GIBNEY, M.J. (2004): The ethics and politics of asylum: liberal democracy and the response to refugees. Cambridge University Press, Cambridge.

GIBNEY, M., HANSEN, R. (2003): Asylum policy in the West: Past trends, future possibilities. World Institute for Development Economics Research Discussion Paper, 68.

GOODWIN-GILL (2016): The Movements of People between States in the $21^{\text {st }}$ Century: An Agenda for Urgent Institutional Change. International Journal of Refugee Law, 28, 4, 679-694.

HOLMES, S.M., CASTANEDA, H. (2016): Representing the “European Refugee Crisis" in Germany and beyond. American Ethnologist, 43, 1, 12-24.

HUYSMANS, J. (2006): The Politics of Insecurity: Fear, Migration and Asylum in the EU. Abingdon, Routledge.

İÇDUGU, A. (2016): Turkey: Labour market integration and social inclusion of refugees, European Parliament, Directorate General for Internal Policies. Published on December, 2016, http://www.europarl.europa.eu/RegData/etudes/STUD/2016/595328/IPOL_STU(2016) 595328_EN.pdf IP/A/EMPL/2016-13, Brussels (18.8.2017).

İÇDUYGU, A. (2015): Syrian Refugees in Turkey: The long road ahead. Washington DC: MPI.

İÇDUGU, A., MILLET, E. (2016): Syrian Refugees in Turkey: Insecure Lives in an Environment of Pseudo-integration. Istituto Affari Internazionali: Global Turkey in Europe. Issue Working Papers 13, http://www.iai.it/sites/default/files/gte_wp_13.pdf (18.8.2017).

İCDUYGU, A., TOKTAŞ, Ş. (2016): After the EU-Turkey refugee deal: A Perspective from Turkey, Briefing for the Netherlands Institute of International Relations "Clingendeal”. https://www. clingendael.nl/publication/after-eu-turkey-refugee-deal-perspective-turkey (18.8.2017). 
İÇDUYGU, A., ŞİMŞEK, D. (2017): Bargaining over Refugees: Turkey’s View. In: Pastore, F. (ed.): Beyond the Migration and Refugee Crisis, Aspen Institute Italia, Roma, 83-91.

KIRKWOOD, S. (2017): The Humanisation of Refugees: A Discourse Analysis of UK Parliamentary Debates on the European Refugee 'Crisis'. Journal of Community \& Applied Social Psychology. 27, 2, 115-125.

KLOOS, S. (2016): The Neo-Ottoman turn in Turkey's Refugee Discourse. Alternatif Politika. 8, 3, 536-561.

MILNER, J. (2014): Protracted Refugee Situations. In: Quasmiyeh, E.F., Loescher, G., Long, K., Sigona, N. (eds.): The Oxford Handbook of Refugee and Forced Migration Studies, Oxford, UK, 176-187.

OSTRAND, N. (2015): The Syrian Refugee Crisis: A comparison of Responses by Germany, Sweden, the United Kingdom, and the United States. Journal on Migration and Human Security. 3, 3, 255-279.

OWEN, D. (2016): In Loco Civitatis: On the Normative Structure of the International Refugee Regime. In: Fine, S., Ypi, L. (eds.): Migration in Political Theory, Oxford University Press, Oxford, 269-290.

UNHCR EXCOM (2009): Conclusion on Protracted Refugee Situations, No. 109.

YÜCEBAŞ, M. (2015): Gaziantep Yerel Basınında Suriyeli İmgesi: Yeni Taşranın Yeni Suskunları: Suriyeliler. Birikim, 311, 38-47.

\section{SHRNUTí}

\section{Legitimizace usazování uprchlíků: analýza humanitárního úsilí v komparativní perspektivě}

Syrští uprchlíci jsou, podobně jako většina násilně přemístěných migrantů ve světě, vystaveni vleklým uprchlickým stavům. Tyto stavy nastávají, když uprchlíci nuceně setrvávají na daném místě po svém původním přemístění pět let i déle, aniž mají bezprostřední vyhlídku na realizaci trvalých řešení (UNHCR ExCon 2009). Vleklé uprchlické stavy jsou velice rozšířené, což svědčí o nedostatečnosti existujících reakcí a také o spíše krátkodobé perspektivě, kterou poskytuje mezinárodní systém ochrany. (Milner 2014, Goodwin-Gill 2016). Bylo právem konstatováno, že tak jak je humanitární režim uplatňován, není schopen poskytnout trvalé řešení a plnohodnotnou ochranu většině uprchlíků ve světě. Také nedokáže odpovídat na integrační potřeby uprchlíků ve vleklém stavu. Vývoj dění vyvolaného syrským konfliktem a následné diskuse o uprchlících dokládají tento deficit v rámci daného režimu. Od počátku konfliktu v Sýrii v roce 2011 hrají při přijímání osob prchajících před násilím zásadní roli tři sousední země - Jordánsko, Libanon a Turecko. K tomuto přívalu uprchlíků zaujala každá z této trojice výrazně odlišný přístup. Turecko zpočátku uplatňovalo politiku otevřených dveří se silným humanitárním podtextem při usazování uprchlíků do určených táborů v jihovýchodní části země.

Jak se zhoršovaly bezpečnostní poměry v Sýrii, prudce vzrůstal počet syrských uprchlíků nejen v zemích na frontové linii, ale také těch, kdo usilovali o vstup do Evropy, jako jakýsi vedlejší efekt konfliktu. Pro tyto uprchlíky se stalo Německo od léta roku 2015 preferovanou cílovou zemí v Evropě. Tento trend je zjevný podle vysokého počtu žádostí o azyl, které obdrželo Německo ve srovnání s dalšími státy Evropské unie. Pokud jde o moderní režim azylového řízení a péče o uprchlíky, humanitární závazky jsou institucionalizovány v systému Spojených národů. Ženevská úmluva o postavení uprchlíků z roku 1951 (zkráceně Ženevská úmluva) položila základy 
humanitárního závazku neposílat uprchlíky zpět tam, kde jsou vystaveni pronásledování, a poskytnout uprchlíkům plnohodnotná práva na ochranu. Zásada „nezapuzovat“ neomezuje počet lidí vpuštěných na dané území (Owen 2016, s. 280) a rovněž neuvádí maximální trvání pobytu. Jak ji vykládá Benhabib, v tomto smyslu Ženevská úmluva vychází z Kantovy zásady všeobecně platného pohostinství (2004, s. 35-36) a je psána v jejím duchu.

Demokratické země zformulovaly vưči uprchlíkům na jedné straně oficiální politiku podle zakořeněných psaných tradic. Ale na druhé straně narážejí demokraticky zvolené vlády nadále na potíže, když mají legitimizovat přijetí uprchlíků v období, kdy je humanitární úsilí uplatňováno výběrově a uprchlíci jsou pokládáni za bezpečnostní problém. Přijímání uprchlíků je obzvlášt nesnadné pro vlády zemí, kde se určité proudy veřejného mínění v případě imigrace a uprchlíků vyslovují záporně k přijímání a nejsou k němu ochotné. Určité výzkumy kritizovaly využití humanitární debaty k ospravedlnění restriktivní azylové politiky (Every, 2008, Chimni, 2000). Několik studií si počíná právě opačně a selektivní využití humanitární debaty hodnotí kriticky, aby přijetí uprchlíků legitimizovaly.

Naše analýza v tomto příspěvku přechází od mezinárodního kontextu humanitárního úsilí ke kontextu státní politiky. Po vylíčení faktického vývoje dění od roku 2011 předkládá článek teoretickou diskusi o důsledcích humanitárního úsilí při přijímání uprchlíků v období po studené válce. V tomto kontextu, charakterizovaném převládnutím bezpečnostního zřetele u azylového řízení a obecně restriktivním přístupem k imigraci, mívají vlády přijímající velký počet uprchlíků pestrou paletu motivů, aby se zapojily do humanitárních akcí. Třebaže většina státních i mezinárodních institucí připouští, že otázka syrských uprchlíků je záležitostí humanitárního úsilí, humanitární zásahy nabývají různých forem v závislosti na společenských, politických a ekonomických poměrech a také na kulturních motivech.

Tato studie je založena na rozboru obsahu výroků, jež pronesli státní představitelé Turecka a Německa, pokud jde o humanitární, ekonomické, kulturní a společenské důsledky přijímání syrských uprchlíků v obou zemích. Celkem analyzujeme výroky, které jsme shromáždili z 41 novinových zpráv z Německa a 54 z Turecka, nalezených ve webových archivech zpravodajství, na webových stránkách novin a ve vládních zdrojích. Výroky patří představitelům vládních stran včetně hlav státu, předsedů vlád a ministrů, zejména zahraničí, vnitra, rozvoje a práce. Dále jsou jejich autory volení a jmenovaní místní politici, jako např́klad starostové a vedoucí krajští činitelé. Zkoumáme pozadí, na němž jsou výroky o tocích syrských uprchlíků proneseny, a potenciální účinek těchto výroků na veřejné mínění a vládní politiku. Zjištujeme, že humanitární debata zpočátku sloužila sociálním, politickým, kulturním a ekonomickým prioritám vlád obou zemí. Oficiální postoj Turecka k humanitárnímu úsilí týkajícímu se těch, kdo prchali před konfliktem v Sýrii, vycházel od počátku z laskavého pojetí silného státu a tradice pohostinnosti, zejména k bratřím v muslimské víře. Na rozdíl od Turecka dával oficiální postoj Německa prioritu ekonomickým důsledkům a byl posílen kulturně historickým důrazem na vedoucí roli této země v Evropské unii. Lze se domnívat, že teprve když kancléřka Merkelová a další činitelé v Německu položili silný důraz na potenciální př́nos uprchlíků německému hospodářství, podnikli činitelé v Turecku právní kroky k usnadnění procedury, jež umožňuje Syřanům s dočasnou ochranou legálně v Turecku pracovat. 


\section{ACKNOWLEDGEMENTS}

The authors gratefully acknowledges the comments received during $13^{\text {th }}$ Imiscoe Annual Conference on a different version of this paper, as well as anonymous reviewers. We also thank Jan Brönneke for his help with the collection and review of German sources. 